This is the Accepted Version of an article that will be published by Elsevier in Third World Quarterly: http://www.tandfonline.com/loi/ctwq20\#.VyhnjaMrLow

Accepted Version Downloaded from SOAS Research Online: http://eprints.soas.ac.uk/22369/

\title{
Class, gender and the sweatshop: on the nexus between labour commodification and exploitation
}

Forthcoming (2016) in Third World Quarterly, special issue on 'Class Dynamics' (accepted version)

\author{
Alessandra Mezzadri, SOAS
}

\begin{abstract}
Drawing on approaches to class stressing the multiplicity of labour relations at work under capitalism and from feminist insights on oppression and social reproduction, this paper illustrates the interconnection between processes of class formation and patriarchal norms in globalised production circuits. The analysis emphasises the nexus between the commodification and exploitation of women's labour, and how it structures genderedwage differentials, labour control, and the high 'disposability' of women's work. The analysis develops these arguments by exploring the case of the Indian garment industry and its gendered sweatshop regime. It illustrates how commodification and exploitation interplay in factory and home-based realms, and discusses how an approach on class premised on social reproduction changes the social perimeters of what we understand as labour 'unfreedom' and labour struggles.
\end{abstract}

Keywords: sweatshop, class, patriarchal norms, commodification, exploitation, India

\section{Introduction}

Feminist analyses have greatly contributed to our understandings of how gender matters for the study of the 'global assembly line' and its implications for development processes. ${ }^{1}$ These analyses have a long history, starting with Ester Boserup's early concerns of how industrial development could potentially marginalise women. ${ }^{2}$ Subsequently, as exportoriented industrialisation seemed to erase women's industrial 'marginalisation', feminist studies evolved into the rich literature on labour 'feminisation'. ${ }^{3}$ This focused on different gendered aspects of the internationalization of factory production, whose trends were initially placed under the microscope by Diane Elson and Ruth Pearson. ${ }^{4}$

As argued by Jennifer Bair, from this period onwards studies on globalization, women and work can be divided on the basis of methodological standpoints. ${ }^{5}$ Early studies focus on the impact of the globalisation of production on women. They interpret gender as a key source of 'horizontal' or 'durable' inequality ${ }^{6}$ crossing global labour markets, which are 'bearers of gender'. ${ }^{7}$ They map the multiple 'circuits of survival' ${ }^{8}$ the global economy opened up for women, and emphasise the harsh deal women get in terms of wages and working conditions. ${ }^{9}$ A second set of studies explore how gender and capitalist relations articulate on the global shopfloor, leading to specific managerial practices of labour control and to the formation of new gendered labour subjectivities. ${ }^{10} \mathrm{~A}$ third set of contributions, like Melissa 
Wright's Disposable Women ${ }^{11}$, analyse how the subordination of women in production also plays out across domains of representation that construct them as intrinsically 'disposable'. Factories build the myth of 'disposability' by appealing to patriarchal obligations mimicking the household division of labour. ${ }^{12}$ Overall, this literature is dominated by three main 'tropes' in its assessment of gendered disadvantages in production; the study of gendered wage-differentials; of labour disciplining and control; and of the social construction of the feminine body as intrinsically 'disposable', 'replaceable', or 'spendable'. Its evolution seems to aspire to incrementally develop a systemic feminist critique to global capitalism. ${ }^{13}$

Also the prolific literature on global commodity and value chains (GGCs and GVCs) including its new avatar focusing on global production networks (GPNs) - has contributed substantially to the study of women and work across global industries. ${ }^{14}$ This literature has been primarily concerned with 'gendering' chains or networks by mapping the incorporation of women as workers across their different tiers. ${ }^{15}$ While numerous studies have focused on factory realms, some noteworthy contributions have also explored links between chains and households. ${ }^{16}$ By deploying gender as an important 'residual' category for the measurement of differential labour outcomes ${ }^{17}$, these studies have contributed to our understanding of gender inequality within globalised circuits.

However, gender inequality is not simply an outcome of globalisation; it also crucially shapes its functioning. ${ }^{18}$ This further expands the possibility for the development of feminist analyses to global commodity chains and networks, as recently argued by Wilma Dunaway. ${ }^{19}$ Aiming to contribute to such analyses, and combining Marxian and Feminist insights, this article illustrates the relation between patriarchal norms and class in the Indian garment industry. This industry organises in a complex global commodity chain or network, stretching across the whole Subcontinent and forming a 'sweatshop regime ${ }^{20}$ characterised by greatly distinct gendered outcomes, patterns of feminisation, and processes of social reproduction. In addressing the relation between patriarchal norms and class, the narrative insists on the nexus between processes of commodification and exploitation of women's work and illustrates how this shapes all three key 'tropes' explaining the gendered disadvantage in production, as identified above; namely, gendered wage-differentials, labour discipline, and the construction of 'disposability'. Given its line of enquiry, the article contributes to the theme of this special issue of 'bringing class back into Development Studies' by illustrating productive points of contact between Marxian and Feminist insights on processes of class formation in developing areas working for global markets.

The article is organised as follows. In section two, the analysis reflects on fruitful ways to understand the relation between class formation and patriarchal norms, drawing from insights based on the work of Silvia Federici, Maria Mies, Barbara Harriss-White and Nandini Gooptu. It highlights how these can be placed in conversation with approaches to class stressing the diversity of labour relations and labour 'unfreedom' within capitalism, as theorised by Henry Bernstein and Jairus Banaji. In the light of this conversation, section three analyses the nexus between processes of commodification and exploitation of women's labour in global production circuits, and how it structures gendered wagedifferentials, labour control and 'disposability'. Section four analyses the Indian garment industry and its sweatshop. It illustrates the different processes of feminisation at work and shows how the nexus between commodification and exploitation structures gendered wage differentials, labour control and disposability for women factory workers and homeworkers. The concluding section derives the implications of the analysis for debates on struggles and 
unfreedom in global production circuits through a feminist lens. The analysis suggests that a separation between struggles against commodification and against exploitation does not hold when it comes to women's labouring experiences.

The empirical evidence informing this paper is based on multiple rounds of multi-sited fieldwork in India, across a span of over ten years. Fieldwork was carried out between September 2004 and July 2005; March and April 2010; January and May 2012; and April and September 2013. It involved different methods of enquiry, ranging from interviews with key informants to semi-quantitative questionnaires and more ethnographic observations, particularly in the urban, peri-urban and rural home-based settings that compose the most decentralised echelons of the garment commodity chain and its sweatshop.

\section{Class, patriarchal norms and social reproduction}

Debates on class and gender have featured prominently in Marxist feminist analyses, despite resenting from the 'unhappy marriage of Marxism and Feminism'. ${ }^{21}$ As underlined by Nancy Folbre, orthodox Marxist and neoclassical economics analyses have theorised the household and reproductive activities in extraordinarily similar ways, despite antithetical understandings of the 'firm'. ${ }^{22}$ Both intellectual traditions have kept a neat separation between public and private sphere. Feminist scholars have rejected this separation and the type of class analysis it generates, as they are greatly problematic.

First, by confining the study of working class formation to the public 'productive' sphere, value-generation is implicitly embedded in a wage-centric view of ethics. ${ }^{23}$ Within this schema, the main struggle for the 'wageless' is entering the wage-relation. ${ }^{24}$ This take on class formation devalues reproductive activities - i.e. 'work' as opposed to 'labour' ${ }^{25}$ - that are re-labelled as unproductive because unpaid or unwaged. The contribution by those engaging in these activities - mainly women - is thus seen as lying outside the process of labouring.

Second, takes on class centred on the public sphere and on production understand 'social difference' as merely produced by capitalism, rather than also structuring its functioning and possessing a certain degree of autonomy. Instead, while capitalism has triggered distinct processes of 'housewifisation' and 'domestication' of women ${ }^{26}$, it neither 'invented' patriarchal norms nor other modes of social oppression, premised on race, caste, ethnicity or geographical provenance. Intersectionality theory ${ }^{27}$ has partially brought this point home, stressing the need to look at the way in which forms of social oppression 'intersect' in experiences of subalterneity, shaping complex 'geographies of power'. ${ }^{28}$

However, often, mere reference to 'intersections' risks remaining a descriptive exercise, simply indicating overlaps between social categories, as in a Venn diagram. The point, instead, is explaining their relation, on the basis of key analytical concerns. In the analysis developed here, the key concern is: how do we understand class and class formation, once we account for forms of social oppression like patriarchal norms? This question does not aim at suggesting the 'primacy' of class per se vis-à-vis other social categories ${ }^{29}$, a position that I find both analytically and politically unhelpful, as often dismissive of social concerns other than class struggle as 'secondary'. Instead, it aims at underlining the need to understand class as a relational category that, as argued by Leela Fernandez in her study of Calcutta's jute mills, is always 'marked by difference, as it is continually been manufactured through 
identity $^{\prime 30}$. Overall, class is shaped by a multiplicity of social relations, and experienced differently by different social groups.

Arguably, beyond the realm of economics, some Marxian analyses have explicitly stressed the multiplicity of labour relations at work under global capitalism, challenging narrow understandings of class. Looking at processes of accumulation and proletarianisation in historical perspective, Banaji has highlighted the co-existence of 'free' and unfree' labour throughout the history of capitalism. In a similar vein, but privileging the current workings of capitalism in its neoliberal phase, Bernstein has convincingly argued that contemporary processes of proletarianisation result in the formation of multiple 'classes of labour', with different relations to means of production, subsistence and reproduction. ${ }^{31}$ In India, these classes are set on a continuum encompassing both formal and informal realms. ${ }^{32}$

From a feminist standpoint, these understandings of class represent an initial fruitful avenue to recover social reproduction as a key dimension of the debate on the relational nature of class. However, arguably, in these accounts, social reproduction remains an area to be 'discovered', in either its relation to labour 'unfreedom' or in the constitution of the 'classes of labour'. In fact, social reproduction does not simply mean labour reproduction. Indeed, people also 'live outside work'. ${ }^{33}$ They may not from the point of view of capital, but they certainly do so from their own standpoint. Nobody simply lives to labour, even when, as for large swathe of the working poor ${ }^{34}$, this ends up being the case in practice.

A number of feminist analyses and/or contributions from female scholars may be deployed to specifically complement Banaji's and Bernstein's analyses. A productive engagement with the relation between class and patriarchal norms would be one accounting for the multiplicity of relations of proletarianisation - or forms of exploitation, as Banaji puts it ${ }^{35}$ generated by capitalism, but at the same time also engaging with a broader understanding of social reproduction anchored to forms of social oppression that mediate class, but also pre-exist it. For this purpose, the work of Federici and Mies, and that of Harriss-White and Gooptu stand out as particularly helpful. Mies and Federici provide solid tools to anchor the study of production to social reproduction. ${ }^{36}$ Harriss-White and Gooptu develop an analysis of class premised on its relation with social oppression. ${ }^{37}$ Let us review these contributions.

In her feminist account of primitive accumulation in Europe, Silvia Federici highlights how this process was 'not simply an accumulation and concentration of exploitable workers and capital. It was also an accumulation of differences and divisions within the working class, whereby hierarchies built upon gender, as well as 'race' and age, became constitutive of class rule and the formation of the modern proletariat'. ${ }^{38}$ In a similar vein, Maria Mies argues that accumulation starts from reproductive realms, which represent the foundations for women's labour appropriation inside and outside the household. Drawing from Rosa Luxemburg's view of capitalism, Mies theorises accumulation as based on multiple and 'ongoing' processes of dispossession, targeting women's unpaid labour as well as nature. ${ }^{39}$

Focusing more specifically on social processes structuring class, and analysing the world of India's 'unorganised' labour, Harriss-White and Nandini Gooptu observe how social institutions and structural differences mediate the very process of class formation. Overall, these institutions and structures represent the complex constellation of inequalities and social differences capital can exploit to proletarianise ${ }^{40}$, condemning different social groups to distinct 'struggles over class' ${ }^{41}$. Karin Kapadia's study of gem-cutters in Tamil Nadu illustrates this point, showing how female gem-cutters represented a wholly different type of 
working class from their male counterparts ${ }^{42}$ - in short, a distinct 'class of labour'. This is because gender ideologies and practices mediated women's entry into the world of labour.

These contributions complement analyses stressing the multiplicity of processes of proletarianisation. By insisting on social reproduction and social oppression beyond class or pre-existing class, but mediating the process of class formation, these insights move the attention from processes of labour exploitation to processes of labour commodification. Ultimately, capitalism 'produces' multiple 'classes of labour' and/or combinations of 'free' and 'unfree' labour by deploying already socially 'classed' bodies. This observation does not aim at demeaning the relevance of exploitation, but it does suggest the urgency to revisit its co-constitutive relation with commodification. I turn to this issue below by focusing on the role patriarchal norms play in global production circuits.

\section{Commodification and exploitation as two sides of the same (gendered) coin}

An understanding of class accounting for both social reproduction and social oppression is crucial to capture women's labouring experiences in global production circuits. Global commodity chains and production networks are 'gendered' socio-economic formations, characterised by high female employment rates across many sectors, like garments ${ }^{43}$ or electronics. ${ }^{44}$ In fact, chains and networks are feminised to their very core, far beyond factory realms. ${ }^{45}$ Patriarchal norms pave their inner socio-economic fabric, even when women's employment rates appear as marginal. Firstly, women can be incorporated as home-based labour, far more 'invisible' than factory labour. Secondly, women's unpaid labour may be mobilised in various ways within the production process. For instance, women's unpaid labour in family-based units may be crucial for the survival of petty commodity production inside globalised circuits. It may work as a reproductive subsidy to the productive household. The study of global production networks should also involve the study of global 'reproduction networks'. ${ }^{46}$

The woman's question in production - and that of disadvantaged groups in general - initially presents itself as a question of differential pricing. The process of labouring has a lower price whenever 'contained' in a feminine body. The body is indeed the first 'machine' invented by capitalism. ${ }^{47}$ Hence, the multiple forms of exploitation ${ }^{48}$ labouring classes experience are structured around multiple forms of labour commodification. This does not mean the two processes - labour commodification and exploitation- can ever be separated, as both take place simultaneously within global production circuits.

In contemporary labour debates, instead, narratives counterpoising commodification and exploitation have gained momentum, based on relatively polarised understandings of Marxist or Polanyian concerns and 'struggles'. ${ }^{49}$ The extent to which one can conceptualise commodification as a primarily Polanyian 'concern' and exploitation as a primarily Marxist 'concern' is subject to intense debate. A thorough review of this debate goes beyond the scope of this paper. ${ }^{50}$ However, one can argue that at least when it comes to labouring experiences, commodification and exploitation cannot be separated; they are two sides of the same coin. Groups subject to harsh forms of social oppression, like women, already enter Marx's 'abode of production' with a lower 'price-tag' stuck to their body, and this sets the basis for higher exploitation rates. In short, when it comes to women, commodification and exploitation are co-constitutive of the experience of labour (and class) subordination. 
This nexus between labour commodification and exploitation is relevant to the study of all key 'tropes' shaping debates on gender, work and global production. This nexus shapes gendered wage-differentials, influenced labour discipline on the shopfloor, and contributes to the social construction of women workers as highly 'disposable'. Let us now move the analysis to the Indian garment industry and its complex sweatshop, where women may be incorporated in 'adverse' ways ${ }^{51}$, marginalised or excluded, while always remaining central to the process of value generation. The case study unveils the distinct ways in which this nexus works in practice in factory and non-factory realms, and illustrates its links with patterns of social reproduction.

\section{The India garment 'mall' \& the patriarchal foundations of its sweatshop 'classes of labour'}

The garment industry in India articulates in a complex commodity chain that incorporates multiple industrial 'clusters'. Product specialisation varies dramatically across clusters, on the basis of local industrial trajectories and the incorporation into different garment commodity markets. Focusing on product specialisation, and looking at India through the eyes of sourcing actors, the entire Subcontinent can be re-imagined as a giant clothing department store - a sort of 'India-mart' where different garment 'collections' are available at different 'floors'. Northern and eastern India, the upper floor of this India-mart, specialise in niche garment lines. Delhi focuses on embroidered ladieswear production, Jaipur owes its fortunes to print-based items, Ludhiana is renowned as the woollens capital of India, and Kolkata has turned into a centre for cheap knitwear and woven garments, like nightwear and kidswear. The lower floors of India-mart instead, namely southern India, are dominated by the mass production of 'basic' items. ${ }^{52}$ Bangalore and Chennai specialise in outerwear or menswear. Tiruppur developed a strong competitive advantage in cotton knitwear. ${ }^{53}$ Mumbai, in the west, although still listed as a key garment centres, is now mainly a centre for the registration of transactions; the 'till' of India-Mart. It hosts the headquarters of some garment companies whose industrial premises are located elsewhere on the basis of processes of 'backshoring'. 54

Patterns of product specialisation are linked to varied labour relations and outcomes. In fact, in India, the garment sweatshop can be conceptualised as a complex and varied 'regime', composed of multiple spaces of work, capital-labour relations, changing on the basis of the 'physical materiality' of production ${ }^{55}$, and with systematic, health-depleting effects for the labouring body. ${ }^{56}$ In the upper floor of India-mart, where niche production is located, factory-labour is composed of male migrants, mainly from Uttar Pradesh (UP) and Bihar. Multiple non-factory labour realms are deployed for value-addition. ${ }^{57}$

Women are mainly incorporated in home-based production, either as family aids in petty commodity units, or as individual homeworkers. In factories, women mainly work in semiskilled activities, like checking, threadcutting or packing. Only few factories employ women as tailors. ${ }^{58}$ The social profile of women home-based workers changes on the basis of the activities performed. Hindu women (of varied castes and civil status) in the NCR engage in needle-based embroidery, known as moti-work. Muslim women (generally from low Muslim castes, and varied civil status) engage in adda-work - a type of embroidery deploying a traditional Muslim handloom. Adda-work connected to export markets takes place in the NCR and in peri-urban and rural UP. ${ }^{59}$ 
Across the lower, southern floors of India-mart, instead, factory work is feminised. In Chennai and Bangalore, around 90 percent of the entire garment factory shopfloor is composed of women workers. Until the early 2000 s, workers mainly came from nearby periurban and rural areas and villages. ${ }^{60}$ Today, significant patterns of long-distant migration are also observed. ${ }^{61}$ In Tiruppur, the labour relations defining the sweatshop combine features of both northern and southern clusters. Male migrants are a significant component of the workforce, but a rising number of migrant women crowd the shopfloor since the $2000 \mathrm{~s} .{ }^{62}$

On the basis of the sketch drawn above, gender differences in the Indian garment industry and its sweatshop can be conceptualised in different ways. A first approach would analyse gender differences in terms of the availability of 'productive', paid employment in factories for women. By adopting this approach, where gender is interpreted in terms of biological sex of the workforce, India's sweatshop regime would 'appear' as feminised only in Southern India, where armies of women workers are visible on the shopfloor. ${ }^{63}$ Notably, this approach sets India as an outlier vis-à-vis other producing nodes of the garment commodity chain, like Bangladesh ${ }^{64}$, Sri Lanka ${ }^{65}$, Mexico ${ }^{66}$, Thailand ${ }^{67}$ or China ${ }^{68}$, where women constitute the majority of the workforce. On the other hand, India as a whole is characterised by low levels of feminisation in manufacturing units ${ }^{69}$, so that observers talk about 'de-feminisation"

A second approach, instead, would entail engaging with the way in which gender structures the very foundation of India's sweatshop regime, by setting the participation of women in certain activities or their exclusion and/or marginalisation in others, on the basis of processes of cost minimisation. In this light, 'feminisation' does not only refer to employment rates in factories, but to the multiple ways in which gender may be mobilised across sweatshops to minimise the costs of different set of activities and tasks. This second, more complex take on feminisation does not simply entail the study of the sex division of labour in factories. It also entails a critical assessment of the variation in the ways in which patriarchal norms can be deployed to maximise processes of surplus extraction across different labour processes. This take is useful to distinguish between qualitatively different processes through which women's labour is appropriated. First, it allows a re-appraisal of the production and labour outcomes characterising the garment industry in the north. Second, it opens up a fruitful avenue to address issues of class formation in the industry, as they interplay with patriarchal norms and social reproduction more broadly.

As noted above, northern garment areas appear as characterised by a highly 'masculine' geography of labour. In the NCR, for instance, male migrants dominate every inch of industrial areas, crowding factories, workshops, and hostels. This 'footloose proletariat ${ }^{71}$ represents the most visible among the 'classes of labour' inhabiting the sweatshop in the north. In non-factory realms, hosting other classes like petty commodity producers and individual homeworkers ${ }^{72}$, women's contribution is higher, although often obscured in statistics. ${ }^{73}$ It strongly intertwines with social reproduction. When women participate as family aids to the petty commodity enterprise, which often covers a (disguised) labouring role in broader production circuits, their contribution is obscured by the leading role played by male family heads. The family works as a unit of production and consumption, and given women's key role in reproductive activities, it is hard to separate their 'productive' contribution. When women work as individual homeworkers, their productive contribution could technically be distinguished from that of other household members who may engage 
in other activities. However, in practice, this is a complex exercise, because both the space and time of all activities - productive and reproductive - intertwine. ${ }^{74}$

Notably in the north, the non-factory realms of production to which women significantly contribute are crucial arenas for processes of value addition, like embroidery. Garments can double their Free On Board (FOB) price once embroidered. ${ }^{75}$ This means that while women's contribution to the production process may look modest, it is still central to value generation. In short, if one adopts a broader take on the relation between gender practices and labour, India's sweatshop regime seems crossed by at least two processes of feminisation; the feminisation of factory production (in the south), and the feminisation of processes of value addition (in the north). In both cases, the sweatshop systematically banks on women's gender disadvantage to minimise the costs of the key industrial activities in distinct market segments. In the south, by feminising a shopfloor producing basic production, employers minimise overall production costs, which are mainly factory-based. In the north, by relegating value addition to non-factory realms and drawing from women's invisible contribution, employers minimise the costs of what otherwise would be expensive ancillary tasks. Overall, women's contribution to the sweatshop is always over-represented at the core of processes of value generation. This is why women may be over-represented at the top and at the bottom of the garment chain and its work hierarchy, at the same time.

Moreover, once the analysis accounts for social reproduction, further insights can be gained on the 'classes of labour' inhabiting the sweatshop. Recent survey data on working and living conditions and workers' social profile in the $\mathrm{NCR}^{76}$ show that the male migratory labourforce engage in multiple processes of labour circulation. The first is yearly circulation, through which a share of migrant workers (roughly one third) goes in and out industrial areas to return to their (generally rural) place of origin. I define the second as labourprocess based circulation'. This indicates the pace through which male workers go in and out factories and workshops in the NCR. Lack of resistance to this process must be understood in relation to the minimal variation in wages and social contributions across units. ${ }^{77}$ The third type of circulation entails workers' 'march' out of the sweatshop, once their working life in the industry terminates, when they are merely $30-35 .^{78}$ This breakdown of labour circulation in distinct sub-components unveils the multiple temporalities shaping sweatshop experiences. In fact, the recovery of 'time' as a key category to assess labour outcomes helps problematizing simplistic, modernising, narratives stressing capital's 'civilising' influence. ${ }^{79}$ These narratives are an example of 'elite-development theory'. ${ }^{80}$

Processes of circulation may often be lonely experiences for male migrants, who generally leave their families behind. Back in the village, women and other family members cover a subsistence role for the household. ${ }^{81}$ Obviously, this depends on the social profile of male migrants, with differences existing between youth and adults with family responsibilities, those owning land or the landless. ${ }^{82}$ However, in all cases, the male experience of circulation should be seen as also resulting from patriarchal norms, that establish who accesses mobility and who is instead left behind.

Overall, the classes of labour of the Indian sweatshop not only have a different relation to social reproduction and patriarchal norms; they are also differently 'produced' on their basis. These distinct classes emerge on the basis of already defined social differences and interplays between production and social reproduction; in other words, on the basis of already 'socially classed' bodies. Both men and women enter the sweatshop carrying this social baggage, which impacts upon their positioning in the garment work hierarchy, their 
payments and labouring experience overall. This baggage sets the 'price' of their labouring bodies while also impacting upon exploitation rates. The next section explores the nexus between labour commodification and exploitation more in depth, and illustrates the ways in which it crosses the processes of feminisation at work in factory and home-based settings, structuring gendered wage-differentials, labour discipline, and 'disposability'.

\section{Gendered wage-differentials, labour discipline \& disposability in and outside the factory}

In her study of East Asia, Stephanie Seguino ${ }^{83}$ shows how the 'comparative advantages of gender disadvantage ${ }^{84}$ were systematically mobilised to boost export competitiveness. The state, always a key agent in the reproduction of 'gender regimes' ${ }^{85}$, channelled female factory employment towards selected industries, to reproduce patriarchal norms despite women's rising employment rates. Men were still able to access better jobs with better pay. Indeed, gender wage-differentials always reflect the status of women as cheaper, secondary workers. Both the household and the factory participate in reproducing these differentials. The household delivers the woman at the factory gates with a lower 'price tag'. The factory takes her in and turns this price into labour surplus. Women are subjected to both the 'family patriarch' and the 'capitalist patriarch'. ${ }^{86}$ Women's lower wage represents, at once, the cost of their social oppression and the higher rate of their exploitation. In this light, gendered wage-differentials always mirror the nexus between commodification and exploitation, shaped by patriarchal norms.

Within the production space, the construction of the woman as a cheap worker is strengthened through discursive practices. ${ }^{87}$ Factories resemble the division of labour inside the home, with male supervisors in positions of authority. While discussed as separate 'tropes', gendered wage differentials and labour control exist in a relation of codetermination. Women enter factories as cheaper workers and are subject to discourses of work that justify their 'cheapness' and impose tight forms of control. Discourses of work appealing to gendered stereotypes perpetuate wage-differentials, and so on, in a circular process. Notably, these discourses may turn the woman into a 'nimble finger' naturally gifted at specific tasks ${ }^{88}$, or into an unskilled worker unequipped for others. Also in relation to gendered patterns of labour control, commodification and exploitation cannot be disentangled. They are set on a continuum of practices through which gender disadvantages in production are manufactured.

Similar reflections can be made with respect to the construction of women workers as inherently 'disposable'. As argued by Wright, 'disposability' is not only the process through which women are socially and materially constructed as a temporary workforce. What makes the reified category 'Third World Woman' more disposable than other subjects after all, as labour informalisation gains momentum also men are exposed to high degrees of precariousness - is that her disposability plays out in both material and representational realms. The myth of global capitalism constructs the woman worker as the bearer of the 'abstract condition of disposability' 89 .

In sum, patriarchal norms mediate women's differential entry into the labouring experience, structure women's shopfloor experience, and also endlessly recreate an imagery of gender subjugation. Also in relation to 'disposability', the inseparable nexus between labour commodification and exploitation holds. In fact, this imagery is strategically deployed to further and justify both processes; namely, the labour of women as initially 'priced' cheaper, 
and the intensity of women's labouring experience on the shopfloor. This said, the ways in which these processes manifest in practice varies considerably. Patriarchal norms are not monolithic, and vary across geographical areas ${ }^{90}$. They also vary across production domains. In the Indian garment sweatshop, these norms structure the labouring practices of women in both factory and non-factory settings, but this is experienced in distinct ways by the woman factory worker and the woman home-worker.

\section{1) The woman garment factory worker in India}

For women factory workers, today's leading 'class of labour' in the feminised garment hubs of Chennai and Bangalore, the 'discovery' of gendered wage differentials by employers in the 1980s worked as a powerful recruiting device. In a somewhat 'classic' trajectory of feminisation, employers substituted male 'troublesome' labour with what they refer to as female more 'docile' and 'loving' labour. This move also made sense in relation to the evolution of product specialisation, which targeted basic clothing to compete with northern export centres, leading to an expansion of manufacturing capacity. ${ }^{91}$

The establishment of larger manufacturing units, coupled with a specialisation in basic garments like jeans, shirts, or jackets, meant that these southern employers placed particular emphasis on strategies at cost minimisation inside factory realms. Following a number of strikes involving the early male factory labourforce, employers started employing women from nearby villages and districts. ${ }^{92}$ The new women recruits were paid a wage that was substantially lower than their male counterparts. By 2005, the wage-differential between the NCR and Bangalore was almost one third. Until then, the most significant labour advocacy work targeting the industry was carried out by the labour NGO Cividep, while (largely male-dominated) unions played a marginal role. Recently, however, also thanks to the establishment of the NTUI-affiliated union GATWU ${ }^{93}$, pro-labour campaigning escalated, and a substantial increase in wage levels finally arrived in 2013. This said, wages still remain lower than in garment hubs dominated by male factory workers.

Wage differentials have been clearly reproduced through a systematic process of social construction of skills. As argued by Samita Sen in her study of the jute industry in West Bengal $^{94}$, the language of skills is always gendered, and skill categories may fully overlap with social categories. The different language deployed by employers to refer to the male and female workforce in the garment industry illustrates this point. While male factory workers are generally referred to as 'tailors', women workers are generally called 'operators'. They are not considered able to make full garments, but simply to engage in single assembly-line sub-tasks. Admittedly, in a context where the technical organisation of production is mainly based on assembly lines, de-skilling is not merely discursive; assemblyline work is characterised by repetitive, tedious and alienating tasks. However, it is reinforced and legitimated via gendered discursive practices. Women are called operators because of their primary deployment in assembly-line production; however, at the same time, they are deployed primarily in assembly-line production because women, in a circular process that reproduce female labour as a cheap input in production.

If gendered discourses of work help employers to reproduce and bank on wage-differentials, they also shaped specific patterns of labour control reproducing patriarchal norms inside factory premises. Supervisors are generally men, and many women workers report genderbased harassment as a key problem. ${ }^{95}$ In Bangalore, gender stereotypes are constantly mobilised to intensify women's work. Here, employers often justify their preference for a 
female workforce on the basis of women's alleged need for less toilet breaks. After all, many employers explain in interviews, women have a 'natural' lower urge to urinate. Male supervisors often deploy abusive comments to discipline workers and remind them of production targets. Many may also engage in physical touching or degrading practices, such as appealing to sexual visual imagery when talking to their 'subordinates' on the shopfloor. ${ }^{96}$ Indeed, the factory reproduces the same structures of oppression women often face in their private sphere. It epitomises the stretch of patriarchal norms across realms of production and reproduction, subjecting women to multiple masters.

Across the feminised shopfloor, employers, managers and supervisors need to ensure the reproduction of the 'disposability' of women workers without threatening the smooth development of production activities and targets. In factory-based mass production, disposability has to be managed carefully. One of the ways in which this process has taken place in both Bangalore and Chennai was through the establishment of a sort of 'five years cycle' of work, after which women generally stop working in one specific industrial premise or company. After five years of service in the same unit, workers would be entitled to bonuses, besides maturing key benefits under the Indian law, like 'gratuity', that is the payment of one-month salary for every year of service. ${ }^{97}$

By 2005 , one of the most common ways in which disposability was guaranteed was through the retention of Provident Fund (PF) contributions, which were only released after the worker 'voluntarily' resigned. More recently, according to Cividep, employers have also developed more aggressive strategies ${ }^{98}$, like the provision of initial loans to new workers, who therefore experience employment in a permanent condition of debt towards employers. Arguably, besides ensuring disposability, this practice also greatly reinforces labour control throughout the employment period. Furthermore, the relatively recent rise in employer-provided dormitories, hosting a new army of women workers migrating from northern areas, is expanding labour control well beyond workers' labouring time, as it is already the case in China ${ }^{99}$ or partially Vietnam ${ }^{100}$. While involving material strategies, disposability is also justified in the realm of representation by appealing to the rhythms of Indian women's life cycle. After all - employers explain - women mainly work 'before getting married', although this is hardly always the case.

All these strategies impact upon labour retention. Ironically, many employers lament high 'attrition rates' (turnover), which can reach 25-30 percent per year ${ }^{101}$. However, this is the price employers pay to reproduce workers as disposable. In centres like Tiruppur, labour control and disposability are reproduced via strategies consistent with labour neobondage. ${ }^{102}$ Here, the Sumangali scheme, already widespread in the ginning and spinning sector, was also deployed by several garment companies to tie young women workers for a period of time in exchange for the promise of a lump sum at the end of the employment contract. ${ }^{103}$ In many instances, employers terminated employment contracts before agreed dates, retaining final payments due to some supposed breach of contract.

\section{2) The woman garment homeworker in India}

As explained in earlier sections of this article, garment nodes engaged in niche production of highly embellished products, like the NCR, make a massive use of non-factory workers, many of whom sweat in home-based settings of different types, particularly, albeit not only, in embroidery activities. Across non-factory settings gendered wage differentials are extremely high. A recent survey of peripheral workers in the last segment of the garment 
chain in the NCR reveals that overall wages for this category of workers are pushed down considerably when women are included in the sample. ${ }^{104}$ These findings refer to women engaged in individual forms of outwork in their own dwelling.

These women combine productive and reproductive activities, with implications for the number of hours they can dedicate to paid work. However, even considering this, their wage seems primarily the result of their limited economic opportunities and, in many cases, of their limited mobility outside their neighbourhood. In embroidery, this is true both in urban and peri-urban and rural settings. A significant portion of embroidery activities for the NCR takes place in rural UP, particularly, albeit not only, in the Bareilly district. ${ }^{105}$ Overall, gendered wage-differentials result from interplays between women's 'double-burden' and lack of alternative employment opportunities. In northern India, and particularly among Muslim communities, women's mobility is far lower than in southern areas. ${ }^{106}$ Women embroidery homeworkers tend to stick to one specific employer and/or contractor. This is particularly the case in peri-urban and rural settings, where real or perceived (but always hierarchical) relations of kinship mediate the employment relation. ${ }^{107}$ However, field findings reveal that also in urban settings women's restricted mobility places them in the hands of those local contractors who are available in given neighbourhoods. ${ }^{108}$

Also in home-based contexts, skills are socially constructed. Gendered discourses of work imply that women are often given 'easy work' involving less significant craft skills and lower pay. However, also in this case, even when women homeworkers access orders involving more intricate, complex designs, they are still paid lower rates because of their gender and more limited opportunities. Overall, both in factories and homework, pay rates hardly reflect productivity. They broadly reflect gendered disadvantages. ${ }^{109}$

In household where the family is a compound unit of work, women are generally merely considered family aids or helpers, rather than 'proper' workers. The wage negotiated for the whole family never includes a direct, separable reward for their labour. Women are in the hands of the family patriarch for the negotiation of the compound wage. Often clubbed into the category 'own-account enterprises', household units perform, instead, a labouring function. It is not a case that data for the NCR shows that own-account operators do not earn substantially more than wage workers in micro-units. ${ }^{110}$ Crucially, the proletarianisation of the family as a unit of production further reinforces women's subordination, as it anchors economic survival to shared forms of self-exploitation in which the male family head emerges, at once, as a labour subcontractor (distributing work among family members); a labour supervisor (controlling the work of family members), and a coworker (himself directly involved in production).

The walls of the neighbourhood economy also bear implications for patterns of labour control. Across non-factory settings, control is not necessarily enforced directly by employers or contractors. In fact, it is already guaranteed and enforced by husbands, fathers and/or neighbours, who significantly limit women's access to employment opportunities. To an extent, employers and contractors can simply bank on the complex system of social control at work across wider domains of social reproduction. If in factory settings patriarchal norms are reproduced on the shopfloor, in non-factory settings the inclusion of work in the private sphere - the home - directly subjects work rhythms to patriarchal norms. In both cases, realms of production and reproduction intimately intertwine to guarantee the appropriation of women's work. To an extent, one could 
characterise the first case as one where the capitalist relation subsumes gendered norms, and the second as one where patriarchal rhythms annex labouring processes.

Finally, for any woman homeworker either engaged in individual outwork or sweating as part of a household unit, 'disposability' is hardly a myth. Women engaged in individualised forms of homeworking are the first workers employers and/or contractors exclude from production circuits during times of crisis or lean seasons. Underemployment and unemployment are the most pressing issue for these workers, who are over-represented among the most peripheral segments of the contracting ladder. ${ }^{111}$ Tellingly, in householdbased production, it may be the family male head to exclude women from paid work during crises. When work availability is limited, the few opportunities available are reserved to male members. Women, merely represented as 'helpers' in interviews with their own family members, can revert to reproductive tasks to subside the declining family wage. Also in this case, the enforcement of disposability is shaped by both productive and reproductive pressures, and plays out across both the material and representational sphere.

Ultimately, both in the case of the women factory worker as in the case of the woman home-based worker, processes of labouring take place in ways that guarantee the commodification of women's labouring bodies as cheap(er) inputs in production while also ensuring higher rates of exploitation. However, these processes manifest in qualitatively different ways. The reproduction of gendered wage-differentials, patterns of labour disciplining and 'disposability' vary on the basis of women's positioning along the employment ladder, showing how capital and patriarchal norms, and spheres of production and reproduction, powerfully articulate in manifold ways, giving rise to varied combinations of forms of commodification and forms of exploitation. Indeed, non-class forms of oppression and realms of social reproduction strongly shape the process of class formation and pave the ways in which distinct categories of workers experience labouring.

\section{Conclusions}

By exploring the case of the Indian garment industry and its highly gendered sweatshop regime, this article has attempted to sketch a fruitful way to analyse the interplay and articulation between class and gender in global production networks. Contributing to the general theme of this special issue, the analysis has combined Feminist and Marxian insights in a framework that conceptualises class formation as starting from realms of social reproduction, and as characterised by interplays between labour commodification and exploitation. The analysis has stressed how these interplays powerfully reproduce gendered wage differentials, tighten control over women's labouring bodies, and reproduce the category 'woman worker' as intrinsically disposable. Indeed, the links between gendered forms of commodification and exploitation crucially shape all the distinct ways in which women are turned into subordinated subjects along the global assembly-line. Obviously, the ways in which these processes unfold vary on the basis of women's different positioning on the employment ladder and production process, as either factory or non-factory, homebased workers. In turn, these depend on the ways in which patriarchal norms mediate the entry of women into the world of labour across distinct factory and non-factory realms. Overall, women are constituted into distinct 'classes of labour' on the basis of gendered dynamics stretching across reproductive and productive domains, and structuring both labour commodification and exploitation. 
The relevance of social reproduction and social oppression in shaping class bears important implications for debates on labour unfreedom and struggle, which I briefly sketch in these concluding paragraphs. First, the tight interrelation between productive and reproductive realms manufactures the female subject into a sweatshop worker in ways that severely limit the possibility of this worker to ever be 'free'. Certainly, the woman worker - as any worker under capitalism, for that matter - is not 'free' in a liberal sense. If something, as spelt out by Banaji ${ }^{112}$, she may be 'free' in a Marxian sense; from subsistence and from means of production. However, even the Marxian conceptualisation of freedom may not fully capture her experienced subordination. Arguably, even when exposed to full dispossession, the woman labouring poor can only be as free as strict gender norms allow. The proliferation of neo-bondage practices in feminised factory realms seems to strongly confirm this point. This is to say that the woman worker is always exposed to multiple forms of social unfreedom. ${ }^{113}$

Second, once production and reproduction are both considered as two key moments of the process of class formation, it becomes impossible to separate 'productive' and 'reproductive' struggles. Or, to put it differently, a sharp, neat distinction between struggles over exploitation and commodification ${ }^{114}$ emerges as increasingly problematic. Indeed, the woman labouring poor - based in a factory or outside - experiences subordination at home and at work simultaneously, and is 'managed' by multiple masters at once. In fact, for large swathes of the labouring poor, for whom, in practice, life is work ${ }^{115}$, one should perhaps rethink the 'social perimeters' of what can be defined as labour struggles. These perimeters should be substantially enlarged, to include those realms of social reproduction that reproduce subordination and oppression and pave processes of class formation. Struggles to ameliorate the life of the woman labouring poor can only be multiple and articulated, targeting the thick walls of the many institutions and spaces where her subordination takes place.

\section{Biographical notes}

Alessandra Mezzadri lectures in Development Studies at SOAS, University of London. Her research interests focus on globalisation and processes of labour informalisation; materialist and feminist approaches to global commodity chains and global industrial systems; labour standards and CSR; gender and globalisation; and the political economy of India. She has investigated in depth the Indian garment industry and explored its complex sweatshop regime, illustrating how working poverty is reproduced in global markets. Her more recent work is published in Oxford Development Studies, Competition and Change, and Progress in Development Studies. Her book 'The Sweatshop Regime' is currently forthcoming. Correspondence to: Alessandra Mezzadri, Department of Development Studies, SOAS, University of London, UK. Email: am99@soas.ac.uk

\section{Funding}

Parts of the fieldwork on which this article is based were financed by the British Academy [SG100684] and ESRC-DfID [ES/I033599/1], in 2010 and 2012, and 2013 respectively.

\section{Acknowledgements}


I would like to thank the editors of this special issue for their support, and the two anonymous reviewers chosen by Third World Quarterly for their helpful and challenging comments. The usual disclaimers apply. Thanks also to Praveen Jha, for asking me to present an earlier draft of this paper in Delhi, in the summer of 2014. That presentation was attended by Sam Moyo, to whom this article is dedicated. 


\section{Notes}

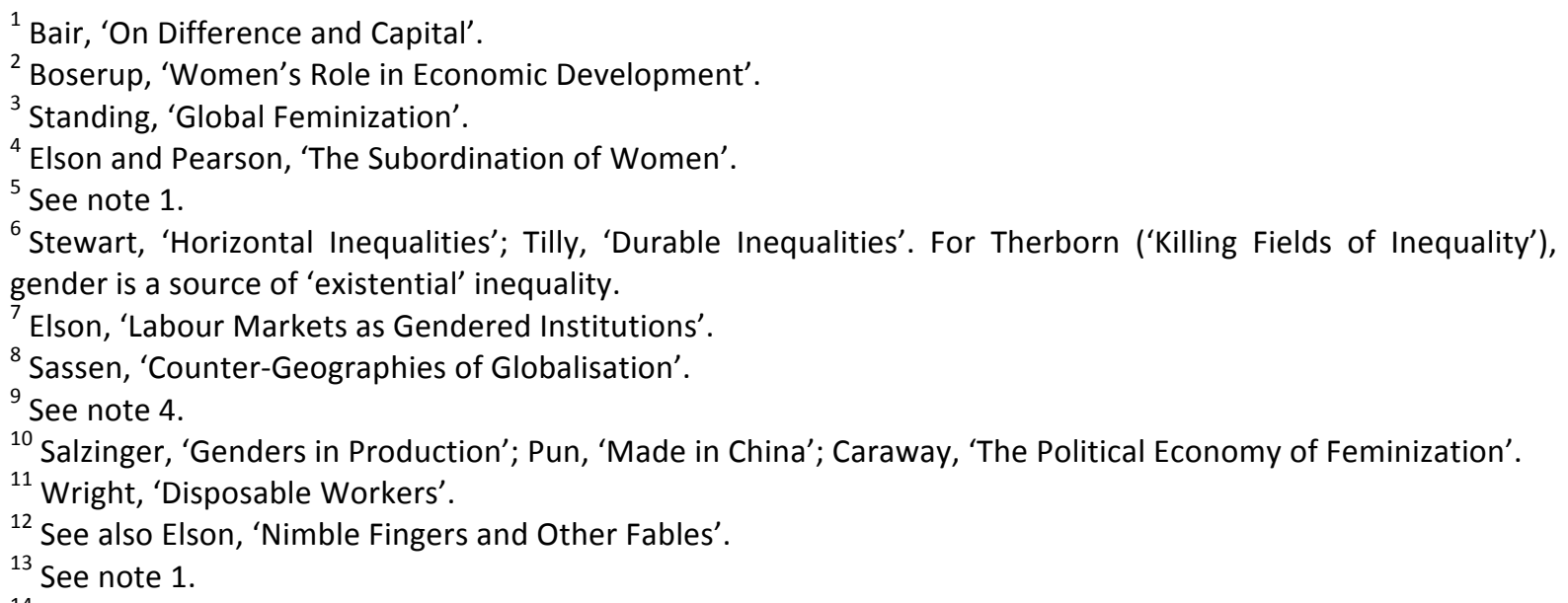

${ }^{14} \mathrm{~A}$ review of the approaches goes beyond the scope of this article. Compare Bair, 'Global Capitalism and Commodity Chains', and 'Frontiers of Commodity Chains'; Coe et al, 'Global Production Networks', and Barrientos et al 'Economic and Social Upgrading'. Here, chains and networks are conceived as 'objects of enquiry' for the study of interplays between patriarchal norms and capital-labour relations.

${ }^{15}$ Joekes, 'Bringing Gender Analysis into the Value Chain'; Barrientos, 'Gender, Flexibility and Global value Chains'; Barrientos et al, 'A Gendered Value Chain Approach'.

${ }^{16}$ E.g. Kelly, 'From Global production Networks to Global Reproduction Networks'.

${ }^{17}$ E.g. Selwyn, Gender, Wage Work and Development'.

${ }^{18}$ Federici, 'Revolution at Point Zero'.

${ }^{19}$ Dunaway, 'Gendered commodity chains'.

${ }^{20}$ Mezzadri, 'Indian Garment Clusters'; 'Backshoring, Sweatshop Regimes and CSR'.

${ }^{21}$ Hartmann, 'The Unhappy Marriage'.

${ }^{22}$ Folbre, 'Hearts and Spades'. Neoclassical approaches to the household are greatly influenced by the work of Gary Becker, widely criticized by feminist economists. E.g. Kabeer 'Reversed Realities'.

${ }^{23}$ Weeks, 'Life Within and Against Work', 'The problem with Work'.

${ }^{24}$ Denning, 'Wageless Life'; Federici, 'Revolution at Point Zero'.

${ }^{25}$ Mitchell et al, 'Life's Work'; Standing, 'Understanding the Precariat'.

${ }^{26}$ Mies, 'Patriarchy and Accumulation'; Federici, 'Caliban and the Witch'.

${ }^{27}$ Crenshaw, 'Mapping the Margins'.

${ }^{28}$ Goettfried, 'Reflections on Intersectionality'.

${ }^{29}$ E.g. Wallis, 'Intersectionality Binding Agent'.

${ }^{30}$ Fernandez, 'Producing Workers'.

${ }^{31}$ Banaji, 'The Fiction of Free Labour', 'Theory as History'. Bernstein, 'Capital and Labour from Centre to Margins'.

${ }^{32}$ Lerche, 'From 'Rural Labour' to 'Classes of Labour'.

${ }^{33}$ Mitchell et al, 'Life's Work'.

${ }^{34}$ Breman, 'Footloose Labour', 'At Work in the Informal Economy'.

${ }^{35}$ Banaji, 'Theory as History'.

${ }^{36}$ Federici, 'Caliban and the Witch'; Mies 'The Lacemakers of Narsapur', and 'Patriarchy and Accumulation'.

${ }^{37}$ Harriss-White and Gooptu, 'Mapping the World of India's Disorganized Labour'.

${ }^{38}$ Federici, 'Caliban and the Witch', 64. For Federici, the attack against 'witchcraft' was to women what enclosures were to poor peasants and landless. In this reading, primitive accumulation always includes multiple processes of dispossession.

${ }^{39}$ Mies, 'The Lacemakers', and 'Patriarchy and Accumulation'. These insights are in line with Harvey's later theorization of 'accumulation by dispossession', although not framed around the 'woman's question'. See Harvey, 'The New Imperialism'.

${ }^{40}$ See also Silver, 'Forces of Labour'.

${ }^{41}$ See note 37.

${ }^{42}$ Kapadia, 'Gender Ideologies'. 
${ }^{43}$ Kabeer, 'The Power to Choose'. Kabeer and Mahmud, 'Rags, Riches, and Women Workers'; Ruwanpura, 'Women Workers in the Apparel Sector'.

${ }^{44}$ Chan et al, 'The Politics of Global Production'.

${ }^{45}$ Dunaway, 'Through the Portal of the Household'; Ramamurthy, 'Feminist Commodity Chain Analysis'.

${ }^{46}$ See note 16.

${ }^{47}$ Federici, 'Caliban and the Witch'.

${ }^{48}$ See note 35.

${ }^{49}$ See Chhachhi, 'Introduction'.

${ }^{50}$ Cf. Burawoy, 'From Polanyi to Pollyanna' and Webster, 'From Critical Sociology to Combat Sport'; see also Selwyn and Miyamura, 'Class Struggle or Embedded Markets'.

${ }^{51}$ See Deshingkar, 'Extending Labour Inspection'; Mosse, 'A Relational Approach to Durable Poverty'; Phillips, 'Informality, Global Production Networks'.

${ }^{52}$ Mezzadri, 'Backshoring, Local Sweatshop Regimes'.

${ }^{53}$ Chari, 'Fraternal Capital'; Carswell and De Neve, 'Labouring for Global Markets'.

${ }^{54}$ See note 52.

55 lbid.

${ }^{56}$ Mezzadri, 'Garment Sweatshop Regimes'.

57 Singh and Kaur Sapra, 'Liberalisation in Trade'; Mezzadri, 'The Rise of Neoliberal Globalisation', and 'Reflections on Globalisation'; Barrientos et al, 'Decent Work in Global Production Networks'.

${ }^{58}$ Mezzadri and Srivastava, 'Labour Regimes'.

${ }^{59}$ Mezzadri, 'Indian Garment Clusters and CSR'.

${ }^{60}$ Kalpagam, 'Labour in Small Industry'; Sharma, 'Globalisation with a Female Face'; RoyChowdhury, 'Labour Activism and Women', 'Bringing Class Back in'; Mezzadri, 'Reflections on Globalisation'.

61 Lyimo, 'Sexual Harrassment'; Jenkins, 'Organizing 'Spaces of Hope”; Kumar, Interwoven Threads'; RoyChowdhury, 'Labour Activism and Women', and 'Bringing Class Back in'.

${ }^{62}$ Chari, 'Fraternal Capital', and 'Fraternal Capital and the Feminsation of Labour'; De Neve, 'Power, Inequality and Corporate Social Responsibility'; Carswell and De Neve, 'Labouring for Global Markets'.

63 Mezzadri, 'Reflections on Globalisation'.

${ }^{64}$ Kabeer, 'The Power to Choose'; Kabeer and Mahmud, 'Rags, Riches and Women Workers'.

${ }^{65}$ Ruwanpura, 'Scripted Performances'.

${ }^{66}$ Salzinger, 'Genders in Production'.

${ }^{67}$ Pearson and Kusakabe,'Thailand's Hidden Workforce'; see also Arnold and Pickles, 'Global Work, Surplus Labour'

${ }^{68}$ Pun et al, 'Final Report on Garment Sector'.

${ }^{69}$ Banerjee, 'How Real is the Bogey of Feminisation'; Ghosh, 'Never Done and Poorly Paid'.

${ }^{70}$ Abraham, 'Missing Labour or Consistent 'De-feminisation".

${ }^{71}$ Breman, 'Footloose Labour'.

72 Mezzadri and Srivastava, 'Labour Regimes'.

${ }^{73}$ Mazumdar and Neetha, 'Gender Dimensions'; John, 'The Problem of Women's Labour'.

${ }^{74}$ Raju, 'The Material and the Simbolic'.

${ }^{75}$ Lal, 'Diagnostic Study'.

${ }^{76}$ Srivastava, 'Capital-Labour Relationships'.

${ }^{77}$ Ibid.

${ }^{78}$ Mezzadri, 'Garment Sweatshop Regimes'.

${ }^{79}$ See note 18.

${ }^{80}$ Selwyn, 'Elite-Development Theory'.

${ }^{81}$ See note 78 .

${ }^{82}$ See note 76 .

${ }^{83}$ Seguino, 'Accounting for Gender'.

${ }^{84}$ Arizpe and Aranda, 'The Comparative Advantages of Women's Disadvantages'.

${ }^{85}$ Connell, 'Gender and Power'.

${ }^{86}$ Kabeer, 'The Power to Choose'.

${ }^{87}$ See note 10.

${ }^{88}$ Elson, 'Nimble-fingers and Other Fables'.

${ }^{89}$ Wright, 'Disposable Women', p. 4; see also Chang, 'Disposable Domestics', and Bales, 'Disposable People'.

${ }^{90}$ Kandiyoti, 'Bargaining with Patriarchy'. 
${ }^{91}$ Mezzadri, 'Globalisation, Informalisation and the State'.

${ }^{92}$ See note 63.

93 Jenkins, 'Organizing 'Spaces of Home"; Kumar, 'Interwoven Threads'.

${ }^{94}$ Sen, 'Beyond the Working Class'.

95 Jenkins, 'Organizing 'Spaces of Hope".

${ }^{96}$ Lyimo, 'Sexual Harassment'.

${ }^{97}$ See note 63.

${ }^{98}$ Cividep and SOMO, 'Richer Bosses, Poorer Workers'.

99 Pun, 'The Dormitory Labour Regime'.

${ }^{100}$ Cerimele, 'Informalising the Formal'.

101 See note 63.

102 Breman, 'Footloose Labour', 'Neobondage'. Neobodage includes labour arrangements involving high degrees of unfreedom, often linked to labour circulation. It differs from old forms of bondage, involving intergenerational family debt. See also Lerche 'A Global Alliance against Forced Labour' and Srivastava 'Conceptualising Continuity and Change'.

${ }^{103}$ SOMO and ICN, 'The Abuse of Girls and Women'; FLA and Solidaridad, 'Understanding the Characteristics of the Sumangali Scheme'. It must be noted that minimum monthly wages may be paid during the work period.

${ }^{104}$ See Mezzadri, 'Labour Regimes in the Garment Sector'; CDPR 'The Oppressive Labour Conditions of The Working Poor'. The survey found that while (almost exclusively male) own-account workers and workers in micro-units can earn on average 6,700 INR under conditions of continuous employment (admittedly rare), women homeworkers earn on average less than 2,000 INR.

${ }^{105}$ Mezzadri, 'The rise of Neoliberal Globalisation'; 'Indian Garment Clusters and CSR'; Unni and Scaria, 'Governance Structures and Labour Market Outcomes'.

${ }^{106}$ See Raju, 'Gendered Geographies'; see also 'The Material and the Symbolic'.

107 See note 59.

${ }^{108}$ See note 58.

${ }^{109}$ See Raju, 'The Material and the Symbolic'.

${ }^{110}$ See note 58.

${ }^{111}$ Mezzadri, 'Free to Stitch or Starve'.

112 Banaji, 'The Fiction of Free Labour'.

${ }^{113}$ See note 111.

${ }^{114}$ See note 49.

${ }^{115}$ Breman, 'At Work in the Informal Economy'. 


\section{References}

Abraham, Vinoj. 'Missing labour or consistent 'de-feminisation'?' Economic and Political Weekly 48 no. 31(2013): 99-108.

AEPC. Indian Apparel Clusters. New Delhi: Apparel Export Promotion Council, 2009.

Arizpe, Lourdes and Josefina Aranda. 'The 'Comparative Advantages' of Women's Disadvantages: Women Workers in the Strawberry Export Agribusiness in Mexico'. Signs 7 no. 2(1981): 453-73.

Arnold, Dennis and John Pickles. 'Global work, surplus labor, and the precarious economies of the border'. Antipode 43 no. 5(2011): 1598-1624.

Bair, Jennifer. 'Global capitalism and commodity chains: looking backward, going forward', in Competition and Change, 9 no. 2(2005): 163-180.

Bair, Jennifer. Frontiers Of Commodity Chain Research. Stanford: Stanford University Press, 2009.

Bair, Jennifer. 'On Difference and Capital: Gender and the Globalization of Production'. Signs: Journal of Women in Culture and Society 36 no. 1(2010): 203-226.

Bales, Kevin. Disposable People: New Slavery in the Global Economy. Berkeley: University of California Press, 2004.

Banaji, Jairus. 'The fictions of free labour: contract, coercion, and so-called unfree labour'. Historical Materialism, 11 no. 3(2003): 69-95.

Banaji, Jairus. Theory as History: essays on modes of production and exploitation. Brill Academic Publishers, 2010.

Banerjee, Nirmala. 'How real is the bogey of feminisation?' In Gender and employment in India, edited by T. S. Papola and Alakh Sharma, 299-317. New Delhi: Vikas Publishing House, 1999.

Barrientos Stephanie, Catherine Dolan and Anne Tallontire. 'A Gendered Value Chain Approach to Codes of Conduct in African Horticulture'. World Development, 31 no. 9(2003): 1511-1526.

Barrientos Stephanie, Gary Gereffi \& Arianna Rossi 'Economic and social upgrading in global production networks: A new paradigm for a changing world'. International Labour Review 150 no. 3-4(2011): 319-40.

Barrientos Stephanie, Kanchan Mathur and Atul Sood. 'Decent work in global production networks'. In Labour in Global Production Networks in India, edited by Anne Posthuma and Dev Nathan, 127-45. Delhi: Oxford University Press, 2010.

Barrientos, Stephanie. 'Gender, Flexibility and Global Value Chains'. IDS Bulletin, 32 no. 3 (2003): 83-93.

Bernstein, Henry. Capital and labour from centre to margins. Keynote address, conference 'Living on the margins, vulnerability, exclusion and the State in the informal economy', Cape Town, 26-28 March 2007. Accessed 4 April 2016.

http://urbandevelopment.yolasite.com/resources/Capital\%20and\%20Labou\%20in\%20the\% 20Margin\%20Bernstein.pdf 
Boserup, Ester. Women's Role in Economic Development. London: Earthscan Publications, 1989.

Breman, Jan. Footloose Labour: Working in India's Informal Economy. Cambridge: Cambridge University Press, 1996.

Breman, Jan 'Neobondage: a fieldwork-based account'. International Labor and WorkingClass History 78 no. 1(2010): 48-62.

Breman, Jan. At work in the informal economy of India, a perspective from the bottom-up. New Delhi: Oxford University Press, 2013.

Burawoy, Michael. 'From Polanyi to Pollyanna: the false optimism of global labour studies'. Global Labour Journal 1 no. 2(2010): 301- 313.

Caraway, Teri L. 'The Political Economy of Feminization: From "Cheap Labor" to Gendered Discourses of Work'. Politics and Gender 3(2005): 399-429.

Carswell Grace \& Geert De Neve. 'Labouring for global markets: Conceptualizing labour agency in global production networks'. Geoforum, 44 no. 1(2013): 62-70.

CDPR. The Oppressive Labour Conditions of the Working Poor in the Peripheral Segments of India's Garment Sector. SOAS: Development Viewpoint (81), 2014. Accessed April 42016. http://www.soas.ac.uk/cdpr/publications/dv/file93820.pdf

Cerimele, Michela. 'Informalising the formal: work regimes and dual labour dormitory systems in Thang Long Industrial Park (Hanoi, Vietnam).' In A Place for Work: Small-Scale Mobility in Southeast Asia edited by Matteo Alcano \& Silvia Vignato. Chiang Mai: Silkworm Books, forthcoming.

Connell, R.W. Gender and Power. Cambridge: Polity Press, 1987.

Chan, Jenny, Pun Ngai and Mark Selden. 'The politics of global production: Apple, Foxconn and China's new working class'. New Technology, Work and Employment 28 no. 2(2013): 100-115.

Chang, Grace. Disposable Domestics: Immigrant Women Workers in the Global Economy. Boston: South End Press, 2000.

Chari, Sharad. Fraternal Capital: Peasant-Workers, Self-Made Men, and Globalization in Provincial India. New Delhi: Permanent Black, 2004.

Chari Sharad'Fraternal capital and the feminisation of labour in South India'. In The International Handbook of Gender and Poverty: Concepts, Research, Policy edited by Sylvia Chant, 446-51. Cheltenham: Edward Elgar.

Chhachhi, Amrita. 'Introduction' to the special issue on 'The Labour Question'. Development and Change 45 no. 5(2014): 895-919.

Cividep and SOMO. Richer Bosses, Poorer Workers: Bangalore's Garment Industry. Joint Report. Netherlands: Somo, 2009.

Coe, Neil M., Peter Dicken and Martin Hess. 'Global production networks: realizing the Potential'. Journal of Economic Geography 8(2008): 271-295.

Crenshaw, Kimberle. 'Mapping the Margins: Intersectionality, Identity Politics, and Violence against Women of Color'. Stanford Law Review 43 no. 6(1991): 1241-1299. 
De Neve, Geert. 'Power, inequality and corporate social responsibility: The politics of ethical compliance in the South Indian garment industry'. Economic and Political Weekly, XLIV no. 22(2009): 63-71.

Denning, Michael. 'Wageless Life'. New Left Review, 66(2010): 79-97.

Deshingkar, Priya. Extending labour inspections to the informal sector and agriculture. Chronic Poverty Research Centre, Working Paper 154. London: ODI, 2009.

Dunaway, Wilma A. 'Through the portal of the household: conceptualising women's subsidies to commodity chains'. In Gendered commodity chains: seeing women's work and households in global production edited by Wilma A. Dunaway, 55-71. Stanford: Stanford University Press, 2014.

Elson, Diane. 'Nimble Fingers and Other Fables'. In Of Common Cloth: Women in the Global Textile Industry edited by Wendy Enloe and Cynthia Chapkis, 5-14. Amsterdam: Transnational Institute, 1986.

Elson, Diane. 'Labour Markets as Gendered Institutions: Equality, Efficiency and Empowerment Issues'. World Development 27 no. 3(1999): 611-627.

Elson, Diane and Ruth Pearson. 'The Subordination of Women and the Internationalisation of Factory Production'. In Of Marriage and the Market: Women's Subordination in International Perspective edited by Kate Young, Carol Wolkowitz and Roslyn MacCullagh, 144-166. London: CSE Books, 1981.

Federici, Silvia. The Caliban and the Witch: Women, the Body and Primitive Accumulation, New York: Autonomedia, 2004.

Federici, Silvia. Revolution at Point Zero: Housework, Reproduction, and Feminist Struggle. Brooklyn, NY: PM Press, 2012.

Fernandez, Leela. Producing workers: the politics of gender, class and culture in the Calcutta Jute mills. Philadelphia: University of Pennsylvania Press, 1997.

FLA \& Solidaridad. Understanding the Characteristics of the Sumangali Scheme in Tamil Nadu Textile \& Garment Industry \& Supply Chain Linkages, 2012. Accessed 4 April 2016. http://www.fairlabor.org/sites/default/files/understanding_sumangali_tamil_nadu_0.pdf

Folbre, Nancy. 'Hearts and Spades: paradigms of household economics', in World Development 14 no. 2(1986): 245-255.

Ghosh, Jayati. Never done and poorly paid: Women's work in globalising India. New Delhi: Women Unlimited, 2009.

Goettfried, Heidi. 'Reflections on Intersectionality: Gender, Class, Race and Nation', in ジ ンダ 一 研 究 第 11 号， (2008) 23- 40. Accessed April 42016. http://www.igs.ocha.ac.jp/igs/IGS_publication/journal/11/jenda_2_heidi.pdf

Harriss-White, Barbara and Nandini Gooptu. 'Mapping India's world of unorganized labour'. Socialist Register 37(2001): 89- 118.

Hartmann, Heidi. 'The unhappy marriage between Marxism and Feminism: towards a more progressive union'. Capital \& Class 3 no. 2(1979): 1-33. 
Harvey, David. 'The 'new' imperialism: accumulation by dispossession'. Socialist Register 40: (2004): 63-87.

Jenkins, Jean. 'Organizing 'Spaces of Hope': Union Formation by Indian Garment Workers'. British Journal of Industrial Relations 51 no. 3(2013): 623-643.

Joekes, Susan. Bringing Gender Analysis into the Value Chain Approach. Brighton: IDS Mimeo, 1999.

John, Mary. E. 'The Problem of Women's Labour: Some Autobiographical Perspectives'. Indian Journal of Gender Studies 20 no. 2(2013): 177-212.

Kabeer, Naila. The Power to Choose: Bangladeshi Women and Labour Market Decisions in London and Dhaka. London: Verso, 2000.

Kabeer, Naila. Reversed realities. Gender hierarchies in development thought, London: Verso, 1994.

Kabeer, Naila and Simeen Mahmud. 'Rags, riches and women workers: export-oriented garment manufacturing in Bangladesh'. In Chains of Fortune: Linking Women Producers and Workers Within Global Markets edited by Marilyn Carr, 133-162. London: Commonwealth Secretariat, 2004.

Kalpagam, Uma. 'Labour in small industry: the case of the garment export industry in Madras city'. In Labor \& Gender: Survival in Urban India edited by Uma Kalpagam, 155-192. New Delhi: Sage, 1994.

Kandiyoti, Deniz. 'Bargaining with Patriarchy'. Gender and Society, 2 no. 3(1988): 274-290.

Kapadia, Karin. 'Gender ideologies and the formation of rural industrial classes in South India today'. Contributions to Indian Sociology 33(1999): 329-352.

Kelly, Philip. F. 'From Global Production Networks to Global Reproduction Networks: Households, Migration, and Regional Development in Cavite, the Philippines'. Regional Studies 43 no. 3(2009): 449-461.

Kumar, Ashok. 'Interwoven threads: Building a labour countermovement in Bangalore's export-oriented garment industry'. CITY 18 no. 6(2014): 789-807.

Lal, Tarsem. Diagnostic Study, Report and Action Plan for the Ready Made Garment Cluster, SISI Okhla. Cluster Development Executive Section, New Delhi: Government of India, 2004.

Lerche, Jens. 'A Global Alliance against Forced Labour? Unfree labour, Neo-liberal Globalisation and the International Labour Organisation', in Journal of Agrarian Change, 7 no. 4(2007): 425-452.

Lerche, Jens. "From "rural labour" to "classes of labour": class fragmentation, caste and class struggle at the bottom of the Indian labour hierarchy'. The Comparative Political Economy of Development: Africa and South Asia edited by Barbara Harriss-White \& Judith Heyer, 67-87. London: Routledge, 2010.

Lyimo, Mahoo. Sexual harassment: an insight into the Indian garment industry, report, Bangalore: Cividep, 2010. Accessed 4 April 2016. http://cividep.org/backdoor/wpcontent/uploads/2013/01/Sexual-Harassment-Report-MahooLyimo-_Oct-2010.pdf

Mazumdar, Indrani and Neetha N. 'Gender dimensions: Employment trends in India, 1993- 
94/2009-10'. Economic and Political Weekly 46 no. 43(2011): 118-126.

Mezzadri, Alessandra. 'The Rise of Neoliberal Globalisation and the New Old Social Regulation of Labour: a Case of Delhi garment sector'. The Indian Journal of Labour Economics 51 no. 4(2008): 603-618.

Mezzadri, Alessandra. 'Globalisation, informalisation and the state in the Indian garment industry'. International Review of Sociology, 20 no. 3(2010): 491-511.

Mezzadri, Alessandra. 'Reflections on globalisation and labour standards in the Indian garment industry: Codes of conduct versus 'codes of practice' imposed by the firm'. Global Labour Journal 3 no. 1(2012): 40-62.

Mezzadri, Alessandra. 'Indian Garment Clusters and CSR Norms: Incompatible Agendas at the Bottom of the Garment Commodity Chain'. Oxford Development Studies, 42 no. 2 (2014): 217-37.

Mezzadri, Alessandra. 'Backshoring, local sweatshop regimes and CSR in India.' Competition and Change 18 no. 4(2014): 327-344.

Mezzadri, Alessandra. Garment Sweatshop Regimes: The Informalisation of Social Responsibility over Health and Safety Provisions. CDPR, SOAS: Working paper 30, 2015. Accessed 4 April 2016. http://eprints.soas.ac.uk/19605/1/Mezzadri_WorkingPaper.pdf

Mezzadri, Alessandra. 'Free to stitch, or starve: capitalism and unfreedom in the global garment industry'. Open Democracy: Beyond Trafficking and Slavery, 2015. Accessed 4 April 2016. https://www.opendemocracy.net/beyondslavery/alessandra-mezzadri/free-to-stitchor-starve-capitalism-and-unfreedom-in-global-garmen

Mezzadri, Alessandra. 'Labour Regimes in the Garment Sector in India: Home-Based Labour, Peripheral Labour'. In Labour regimes in the Indian garment sector: capital-labour relations, social reproduction and labour standards in the National Capital Region (NCR), report by Alessandra Mezzadri and Ravi Srivastava. CDPR: SOAS, 2015. Accessed 4 April 2016. https://www.soas.ac.uk/cdpr/publications/reports/file106927.pdfMies, Maria. The Lace Makers of Narsapur: Indian Housewives Produce for the World Market. London: Zed, 1982.

Mies, Maria. Patriarchy and Accumulation on a World Scale: Women in the International Division of Labour. London: Zed, 1986.

Mitchell, Katharyne, Sallie. A. Marston and Cindi Katz. 'Life's work: an introduction, review, and critique'. Antipode 35 no. 3(2003): 415-442.

Mosse, David. 'A Relational Approach to Durable Poverty, Inequality and Power'. The Journal of Development Studies 46 no. 7(2010): 1156-1178.

Pearson, Ruth and Kyoko Kusakabe. Thailand's Hidden Workforce: Burmese Migrant Women Factory Workers. London: Zed, 2012.

Phillips, Nicola. 'Informality, global production networks and the dynamics of 'adverse incorporation'. Global Networks 11(2011): 380-397.

Pun Ngai. Made in China: Women Factory Workers in a Global Workplace. London: Duke University Press, 2005. 
Pun Ngai. 'The Dormitory Labor Regime: Sites of Control and Resistance for Women Migrant Workers in South China'. Feminist Economics, 13(2007): 239-258.

Pun, Ngai, Liu, Aiyu , and Lu, Huilin. Final Report on Garment Sector of the Greater Shanghai Region. London, SOAS: Mimeo, 2015.

Raju, Saraswati. Gendered Geographies: Space and Place in South Asia. New Delhi: Oxford University Press, 2011.

Raju, Saraswati. 'The Material and the Symbolic: Intersectionalities of Home-Based Work in India'. Economic and Political Weekly 48 no. 1(2013): 60-68.

Ramamurthy, Priti. 'Feminist commodity chain analysis: A framework to conceptualise value and interpret perplexity'. In Gendered commodity chains: seeing women's work and households in global production edited by Wilma A. Dunaway, 38-54. Stanford: Stanford University Press, 2014.

RoyChowdhury, Supriya. 'Bringing Class back in: Informality in Bangalore'. Socialist Register 51, Transforming Classes (2015): 73-92.

RoyChowdhury, Supriya. 'Labor activism and women in the unorganized sector, garment export industry in Bangalore'. Economic and Political Weekly, 40 no. 22-23(2005): 22502255.

Ruwanpura, Kanchana. 'Women workers in the apparel sector: a three decade ( $r$ )-evolution of feminist contributions?' Progress in Development Studies 11 no. 3(2011): 197-209.

Ruwanpura, Kanchana. 'Scripted performances? Local readings of 'global' health and safety standards: The apparel sector in Sri Lanka'. Global Labour Journal 4 no. 2(2013): 88-108.

Salzinger, Leslie. Genders in Production. Berkeley: University of California Press, 2003.

Sassen, Saskia. 'Counter-Geographies of Globalization and the Feminization of Survival'. Journal of International Affairs, 53 no. 2(2000): 504-524.

Seguino Stephanie. 'Accounting for Gender in Asian Economic Growth'. Feminist Economics 6 no. 3(2000): 27-58.

Selwyn, Benjamin. 'Elite development theory: a labour-centred critique'. Third World Quarterly 37 no. 5(2016): 781-799.

Selwyn, Benjamin. 'Gender wage work and development in North East Brazil'. Bulletin of Latin American Research 29 no. 1(2010): 51-70.

Selwyn, Benjamin and Satoshi Miyamura. 'Class Struggle or Embedded Markets? Marx, Polanyi and the Meanings and Possibilities of Social Transformation'. New Political Economy 19 no. 5(2014): 639-661.

Sen, Samita. 'Beyond the 'working class': women's role in Indian industrialisation'. South Asia: Journal of South Asian Studies 22 no. 2(1999): 95-117.

Sharma, Miriam. 'Globalisation with a female face: Issues from South Asia', Exploring Gender Relations: Colonial and Post-colonial India edited by in Shakti Kak \& Biswamoy Pati, 463-90. New Delhi: Nehru Memorial Museum and Library, 2005.

Singh, Navsharan and Mrinalini Kaur Sapra. 'Liberalisation in trade and finance: India's 
garment sector'. In Trade Liberalisation and India's Informal Economy edited by Barbara. Harriss-White and Anushree Sinha, 42-127. New Delhi: Oxford University Press, 2007.

SOMO and ICN. The abuse of girls and women workers in the South Indian textile industry. SOMO and ICN Joint Report, 2014.

Srivastava, Ravi. 'Conceptualising continuity and change in emerging forms of labour bondage in India'. In India's unfree workforce: of bondage old and new edited by Jan Breman, Isabelle Guérin and Aseem Prakash, 129-147. New Delhi: Oxford University Press, 2009.

Srivastava, Ravi. 'Capital-Labour Relationships in Formal Sector Garment Manufacturing in the Delhi National Capital Region of India'. In Alessandra Mezzadri and Ravi Srivastava Labour regimes in the Indian garment sector: capital-labour relations, social reproduction and labour standards in the National Capital Region (NCR). CDPR: SOAS, 2015. Accessed April 4 2016. https://www.soas.ac.uk/cdpr/publications/reports/file106927.pdf

Standing, Guy. 'Global Feminization through Flexible Labor: A Theme Revisited'. World Development 27 no. 3(1999): 583-602.

Standing, Guy. 'Understanding the precariat through labour and work.' Development and Change 45 no. 5(2014): 963-980.

Stewart, Frances. 'Horizontal Inequalities: A Neglected Dimension of Development'. Working Paper 81, Queen Elizabeth House, University of Oxford, 2002. Accessed April 42016. http://www3.qeh.ox.ac.uk/pdf/qehwp/qehwps81.pdf

Therborn, Goran. The killing fields of inequality. Cambridge: Polity, 2013.

Tilly, Charles. Durable Inequality. Berkeley: University of California Press, 1998.

Unni, Jeemol and Suma Scaria. 'Governance structure and labour market outcomes in garment embellishment chains'. Indian Journal of Labour Economics 52 no. 4(2009): 631-650.

Wallis, Victor. 'Intersectionality's binding agent'. New Political Science 37 no. 4(2015): 604619.

Webster, Edward. 'From critical sociology to combat sport? A response to Michael Burawoy's 'From Polanyi to Pollyanna: the false optimism of Global Labour Studies'. Global Labour Journal 1 no. 3(2010): 384-387.

Weeks, Kathi. The problem with work: Feminism, Marxism, Antiwork politics and Postwork imaginaries. Durham: Duke University Press, 2011.

Weeks, Kathi. Life Within and Against Work: Affective Labor, Feminist Critique, and PostFordist Politics. Ephemera: Theory and Politics in Organization 7 no. 1(2007): 233-249.

Wright, Melissa. Disposable Women and Other Myths of Global Capitalism. New York: Routledge, 2006. 